\title{
長岡市旧中島浄水場配水塔の造形設計について \\ STUDY ON THE DESIGN IN THE FORM OF \\ THE FORMER NAKAJIMA WATER PURIFICATION PLANT WATER TOWER \\ IN NAGAOKA CITY
}

\author{
平山育男*
}

Ikuo HIRAYAMA

\begin{abstract}
I considered the form of the water tower at the former Nakajima water purification plant in Nagaoka city from the viewpoint of design, and the following points become clear.

The adoptions of the Jince type tank, the outer wall and the cylindrical tower bent circumference wall surface meet all the environmental condition in cold districts. As a result, it became that the vertical plane of the water tower showed a certain characteristic style. The water tower was designed with the results searched the technique suitable for Nagaoka area and the form in consideration of an environmental condition in winter.
\end{abstract}

Keywords : Water tower, Nagaoka city, Jince tank, Coldproof wall 配水塔, 長岡市, インツェタンク，防寒壁

\section{1.はじめに}

長岡市旧中島浄水場は長岡市水道町に所在する。この施設は昭和

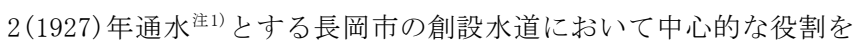
果たし、現在は配水塔（水道タンク）注2)、監視室棟、唧筒室棟、予 備発電機室棟が国の登録有形文化財とされている。配水塔は後述の ように全高 $42 \mathrm{~m}$ 余、水槽タンクは $617 \mathrm{~m}^{3} の$ 容積を備え、戦前期にお いては全国でも有数の規模を誇った。ところでこの配水塔の水槽夕 ンクを支える 6 層注 ${ }^{3)}$ の円塔脚部注4) 2 層目以上の各層床面中央には暖 房用とされる穴が設けられるが、これは戦前期までの建設となる公 共上水道の配水塔には未見のものである。また、この配水塔では水 槽タンクに下部を反転させて凸形とするインツェ型を採用し、配水 塔の立面形状は円塔脚部と水槽タンクの接続部分が極端にすぼまる、 いわゆるこけし型となるが、これらも戦前期の公共上水道における 配水塔では類のないことが判明した。

そこで本稿においては、これらの設備と造形がどのような考えに 基づき長岡市旧中島浄水場配水塔の設計に結実したのかを明らかに することを目的とするものである。

長岡市の上下水道施設については、昭和 2 (1927) 年の竣功を記念 してまとめられた『長岡市上下水道小誌』、竣功時とされる図面類 が一部残るが、本稿ではこれらに加え当時の新聞、上水道関連資料 や実際の配水塔の考察を通し、この問題を考えて行きたい。

従来、この旧長岡市中島浄水場配水塔について『長岡市上下水道 小誌』注5)では、後に詳述するように

水槽は鉄筋混凝土造円塔上を安置し其周囲には四呎六吋の間隔 を以て直径四十五吹の外壁を作り水槽を包囲し冬期に於ける防 寒の設備とす
とされ、加えて、

万一冬季水槽内水結の盧あるを慮り最下層床上に煖爐を設備し

円筒及水槽の内部中央を貫きて煙突を設け得る設備をなせり とあるように防寒施設の計画のなされたことが記される。但し、イ ンツェ式水槽導入とその経緯は同書に記載がない。また後者の煖爐、 煙突は長岡市水道局に残される “配水塔竣工図”に記載があるため、 計画に留まったのか疑問が残る。

なお、水槽に外壁を設け防寒壁とする考えは昭和戦前期、広く国 内外認識され 注6)、高岡市の旧配水塔においても採用された注7) もの の、煖爐や煙突の施設はこの時期、他に類例がない。

\section{2. 長岡市旧中島浄水場と配水塔の施設と設計者について 2-1 長岡市旧中島浄水場と配水塔の施設}

長岡市における上水道敷設は、明治 34 (1901) 年以来の課題とされ、 下水道敷設と並行して議論が行われた注8)。敷設の計画は大正 2 （1913）年、大正 9(1920) 年注9) にあったが、いずれも頓挫した。そ こで大正 11(1922) 年になって上水道施設の設計を中島鋭治、下水道 施設を鶴見一之とする計画が出され、関東大震災後の大正 13 (1924) 年 1 月に工事が着手されて翌 4 月に起工式があり、昭和 2 (1927) 年 3 月に竣工式を挙行したのが長岡市における創設の上下水道である。

完成した創設の上水道の施設は信濃川東岸の中島浄水場隣接地内 において伏流水を取水し、場内でろ過後、配水塔へポンプにより揚 水し、自然流下で配水を行うものであった。なお、昭和 46(1971) 年 4 月になって信濃川上流に妙見浄水場が建設され、中島浄水場は平

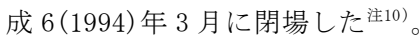

当初における上水道施設の計画給水人口 6 万人、第 1 期工事とし 
て 4.5 万人とされ、 1 人 1 日最大給水量 4 立方尺（約 111 l)、 1 日 最大給水量 180,000 立方尺 (約 $5,000 \mathrm{~m}^{3}$ ) と寸る計画がなされた ${ }^{2} 11$ )。

配水塔は $\mathrm{RC}$ 造の円塔脚部 6 層目上部に鋼鉄製の水槽タンクを据え る形式である。円塔脚部は下部直径が 30 フィート6インチ $(9.30 \mathrm{~m}) 、$ 厚 2 フィート $(0.61 \mathrm{~m})$ 、上部直径は 22 フィート $(6.71 \mathrm{~m})$ とする。円塔 脚部表面周囲には $1 / 20$ の傾斜をつけ、周囲に 8 本の付柱を配する。 水槽タンクは最大径 36 フィート $(10.97 \mathrm{~m})$ 注 12$)$ 、最大高 24 フィート 6 インチ $(7.47 \mathrm{~m})$ 注13 )、最下部から 7 フィート 6 インチ $(2.29 \mathrm{~m})$ の部 分から円錐型にすぼまり、底面は凸型に反転する注14)。平面半径は 22 フィート $(6.71 \mathrm{~m})$ 、反転高さは最大 4 フィート 6 インチ $(1.37 \mathrm{~m}) 、$ 反転する曲面の半径は 22 フィート $7 \frac{1}{2}$ インチ $(6.90 \mathrm{~m})$ とする注 15$)$ 。ま た、水槽タンク周囲には 4 フィート 6 インチ $(1.37 \mathrm{~m})$ の巾を持たせ歩 廊が巡り、直径 45 フィート (13.72m)の外壁が設置され焦16)、更に外 壁外に歩廊が設けられる。配水塔の高さは基準面から塔屋根避雷針 下までが 137.5 フィート (41.88m) 注17)、水槽タンク最高水面まで の高さが 115 尺 (34. 85m)、水槽タンク容積は容積 21,777 立方フィー 卜 $\left(617 \mathrm{~m}^{3}\right)$ と寸る注18)。水槽タンクの屋根は小屋組がワーレントラ スで、中央で水槽タンク下部から延びる中空の円柱がこれを受ける。

\section{2-2 長岡市旧中島浄水場と配水塔の設計者}

浄水場施設の全体設計は中島鋭治注19)、配水塔の設計は前橋市敷 島浄水場配水塔の設計も行った注20) 金井彦三郎とされる注21)。

中島鋭治注22) は安政5 (1858) 年に生まれ、東京大学理学部土木工学 科を卒業し、明治19 (1886) 年に助教授に任ぜられ、同年に留学した。 当初は橋梁工学を修めたが、後に衛生工学へ転じ、アメリカ、イギ リス、フランス、オランダを巡りドイッで学び、明治23(1890) 年に 帰国を促され東京をはじめとする上下水道の計画にあたることとな った。明治29 (1896) 年からは帝国大学教授となり、明治34 (1901) 年8 月には海外視察として、アメリカ、イギリス、ベルギー、オランダ、 フランス、スペイン、イタリア、オーストリア、ハンガリー、ドイ ツ等を巡りロンドンに戻り、デンマーク、スウェーデン、ロシアを 経て翌年7月に帰国している。なお、中島は寡作として知られ、事典 類の共著以外では、幾つかの著作で “序”を記すのみで、配水塔に ついての具体的な言説を見ることはできない注23)。

一方、金井彦三郎注24) は慶応3 (1867) 年生まれで、攻玉社で学び、 東京府 (市)、後に鉄道省へ転じた。東京府技師としては関東大震災 以前における旧東京市内の鋼鉄製橋梁の設計に多く携わり、鉄道省 では東京駅の監修や高架線の建設に当たった。後には攻玉社などで 教鞭をとり、昭和7 (1932) 年に没したが、渡航や留学、視察の記録は 残らない。金井は技術的な著作を多数残しているが、管見の限りこ こに配水塔についての記述は見出せない。但し、金井には未刊書原 稿として『配水塔』なる書籍が準備されたとされている注25)。

\section{3. 旧中島净水場配水塔と各層に見られる床面の穴}

この配水塔の円塔脚部 2 層目から 6 層目までの各層床面中央部に は $900 \mathrm{~mm}$ 角程の大きさとなる四角形の穴があり、現状では大半が木 製の蓋で覆われる。この穴は従来、冬期間における水槽タンク保温 に用いられた、もしくは荷揚用に用いられたとされるが、真偽は不 明である。ここでは先ず、この穴が建設工事以来どのように用いら れたのかを明らかとしたい。

\section{3-1 新聞報道に見るエ事中の旧中島浄水場配水塔と各層の穴}

配水塔の完成は大正15 (1926) 年8月の通水を目指しながらも、予定 よりやや遅れた。配水塔を用いた通水は大正15 (1926) 年10月頃、外 構も含めた全体の完成は昭和2 (1927) 年3月と考えられる注26)。

ところで建設中、新聞報道において、この穴はどのように報道さ れたのであろうか。以下ではまずその点を確認したい。

『北越新報』大正 15 (1926) 年7月 13 日号では、同月 3 日からの給水 工事の申込みを受け

肝腎の浄水場の状况が何の程度進捗し居るか果して当局の言明 する様に八月には通水出来るや否や注27)

とする点を確認するため、記者が “中島浄水場を観る”と題して以 下のような記事をまとめた。

人夫は夫々炎天下に各部署に就て懸命に働く筈で八月の通水そ れは第三、四号濾過池も完成して居るしタンク築造工事も配水 塔の中央に暖房用のストーブ煙道があつた為此処よりロープを 通じ塔上に天木を立て鉄板は全部外から捲揚機で引揚げる事が 出来た為予想以上には進捗したが外部の三吋鉄網コンクリート 工事其他附帯工事もあるから竣工期限より多少は遅ることして も来月中旬位迄には完成するであらう注28)

記事によると配水塔中央には暖房に用いるストーブの煙道用の穴 が設けられ、ここからロープを通じさせたため予想以上に仕事は進 捗したという。つまり、この穴は本来、暖房用ストーブの煙道であ ったが、工事期間中は資材の移動にも用いられたことが判明する。

\section{3-2 『長岡市上下水道小誌』に見る旧中島浄水場配水塔と各層の穴}

一方、設計段階でこの穴はどのように考えられていたのであろう か。そこで配水塔の竣工の昭和 2 (1927) 年3月に発刊された『長岡市 上下水道小誌』における配水塔についての記録を次に見ておきたい。

（チ）配水塔

配水塔は其数一箇所にして水槽は鋼鉄円筒形にして直径三十六 呎底は円推形の一部及凸形欠球より成り深二十一吹乃至二十四 吹容積二万千七百七十七立方呎とす

水槽は引入管引出管及余水吐の三管を設け何れも内径十六吋の 鋼管にして水槽の下部に於て伸縮管を設け水槽内最高水面の高 は基面点上百九十尺（現在地盤より百十五尺）とす 水槽は鉄筋混凝土造円塔上を安置し其周囲には四呎六时の間隔 を以て直径四十五吹の外壁を作り水槽を包囲し冬期に於ける防 寒の設備とす外壁の構造は円塔上に於ける支柱上に鉄材を以て 架構を作り其外側は鉄鋼混凝土造とし内側は木材を以て全部を 張り詰む水槽と外壁との間には其上部及下部に於て水槽の周囲 を一周すへき歩道を作り上下両歩道は階段に依りて連結す 水槽上屋根は鋼材を以て製作せる八箇の構桁及十六箇の $\mathrm{T}$ 形桁 を架し其勾配を三十度とし更に其上部に山形鋼を架渡し縦横四 吹以下とし表面は鉄板を以て全部を覆ふ

屋背上には巾二吹長三呎の出入口一箇所を設け水槽周囲の上部 歩道より直に屋背に出入するを得せしむ

水槽を支持する円塔は鉄筋混凝土造にして表面は二十分の一の 傾斜をなし上部の側壁中心より直径二十二吹下部同三十吹六吋 厚二呎にして基礎は混凝土造とし内径二十一呎外径五十一呎厚 六呎の環状をなし其底部の高さは基面点上五十八尺（現地盤以 下十七尺）とす

基礎底面に於ける最大圧力を毎平方呎三、三四噸にして建設地 
地質は堅硬なる砂利層なるを以て此圧力に対して安全なるもの とす

円塔上部の高は基面点上百六十五呎 (現在地盤上九十五呎)にし て内部には鉄筋混凝土造床四層を以て間仕切をなし倉庫其他の 用に供せしむ各室の高さは十四呎六乃至十四呎九とす而して万 一冬季水槽内水結の盧あるを慮り最下層床上に煖爐を設備し円 筒及水槽の内部中央を貫きて煙突を設け得る設備をなせり注29) ここで注目すべきは、文末の“万一”以下における箇所である。 この部分を口語訳すれば

万一、冬季に水槽内が氷結する懸念のあることを考慮し、最下
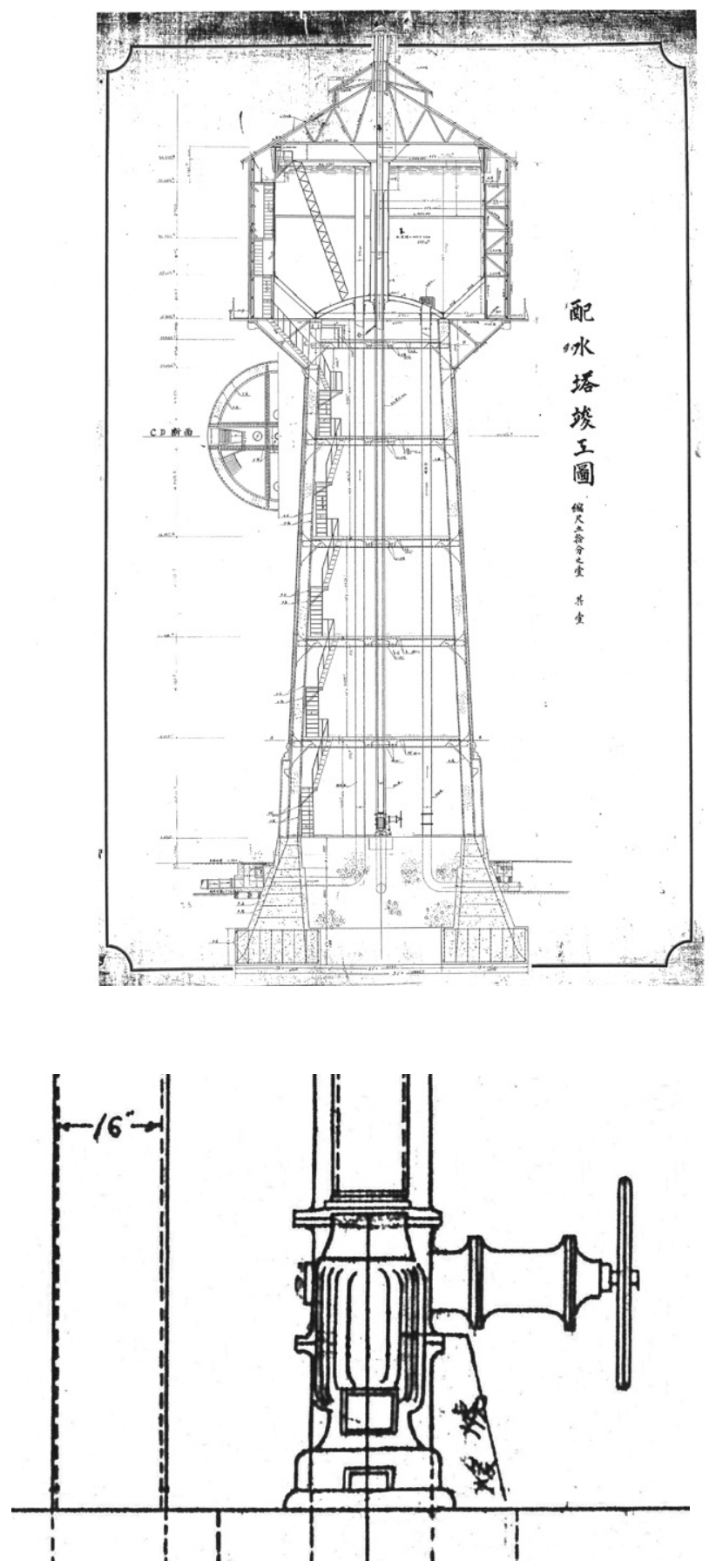

図 1 長岡市旧中島浄水場 配水塔竣工図 長岡市水道局所蔵 上: 全体図下: 初層中央 “煖爐” 部分拡大
層床上に煖爐（=暖炉）を設備し、円塔及び水槽の内部中央を

貫いて煙突を設けることが出来る設備を行った となる。この文章を厳密に解釈寸れば、竣功において円塔脚部中央 には“煙突を設けることができる設備”とするのみで煙突は設けら れていなかったと考えることができ、この設備が前述したように工 事に際して資材の運搬に用いられた煙道と寸ることができよう。

ところで、長岡市水道局には図1に示寸 “配水塔竣工図”が残る。 図面では円塔1層目に“愋爐”の書込みがあり、上方に 2 本の線が延 び、これが煙突を示すと考えられる。そのため、『長岡市上下水道 小誌』では煖爐及び煙突を“設け得る設備”とはしたものの、竣功 時に煙突を配備したと考えることもできるのである。実際はどのよ うな装備がなされたか、以上の資料では明らかではない。

ところで稼働後の配水塔では、昭和11 (1936) 年における大雪後の 様子が以下のように報告される。

水槽台は約 2 尺厚の鉄筋コンクリート円筒壁で、給水配水の鉄 管は其の内部に設備してある。鉄製タンクは餃壁を以て囲まれ て居るので愈々これから市内に給水される時の水温も冬期外気 より10度以上温いから、寒雪害に対して憂はない様な次第であ る。以上のように創立当時から雪国の水道、寒地の水道として 相当考慮の上設備したもので《中略》配水塔の如きも設計には 内部基礎面より屋根裏まで暖房の設備が出来る様に工夫されて 居るから、曾て其の必要を認めないので実施せずに居る注30)

つまり、配水塔は基礎面から屋根裏まで暖房のできるように工夫 がなされたものの、これまでその必要を認めないため実施はなされ ないとあり、運転後も暖房の設備はなかったことが分かる。

なお、長岡市における厳寒期 1 月、2月の平均気温は、記録の残る 明治38 (1905) 年から上水道竣功までの昭和 $2(1927)$ 年では、1月が $0{ }^{\circ} \mathrm{C}$

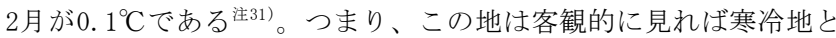
言えるものの、それ程の防備が必要ではなかったとの考えに至る。 そこで工事費及び竣功以後の維持費に影響のある愋爐の設置は敢え て見送り、煖爐以外の防寒設備による運用を当面は見ようとしたも のが、当初工事の方針で、その結果が前述した昭和11(1936)年の報 告であったと言えよう。

\section{3-3 図面類などに見る旧中島浄水場配水塔における排煙処理}

この様に見てくると配水塔の建築に際しては煙突を設置できるよ う、円塔脚部では各層床中央に穴だけが設けられたことが明らかと なった。即ち現状の各層床面に見られる穴が、この煙突を通すため のものであったと考えることができるのである。

ところで、この配水塔で煙突は設置されなかったが、“煙突を設け ることができる設備”とされたため、煙突を実際に設置した場合に おける最終的な排煙、排気の計画もなされたと言える。以下では、 近年に長岡市水道局から提供された配水塔設計図の読解などからそ れらの点を考察してみたい。

配水塔の煙突は計画において円塔脚部2層目から6層目の各層中央 に開けられた穴を経て水槽タンク下部に延び、この後における排煙 処理は『長岡市上下水道小誌』の引用末尾で

円筒及水槽の内部中央を貫きて煙突を設け得る設備をなせり とあるように、煙はこの中空円柱を通して排出される方針であった ようだ。そこでこの様な観点から図面類に当たると以下のことが判 
明する。図面では “第八号” 及び “配水塔” とする図面の “AB断面” “基礎平面”と寸る平面図の中央に煙突と考えられる部材に “煖爐” の書き込みを確認できる。そして “配水塔竣工図” とされる断面図 を見ると、配水塔中央部には円塔脚部1層目から6層目、加えて水槽 タンク下部へ向けてまっすぐ煙突が上部へ延び、これらは更に水槽 タンク中央部の中空円柱内を通って屋根頂部に続いている。

また、小屋組以上の詳細は “屋根一般図” “屋根小屋組詳細図” と する図面により確認できる。図面によれば配水塔の屋根は円錐型で、 中央から放射状に8等分の位置にワーレントラスとなる小屋組が配 される。小屋組陸梁の中央を煙突が貫くため、小屋組陸梁中央は同 高さの煙突周囲に配される環状の材にリベット止され、更に小屋組 陸梁と中空円柱は斜材の山形鋼により補助的に接続される。図面に よると配水塔の大屋根は全体が円錐型で、中央の半径7フィート程が 2フィート程高い小屋根で、周囲との段差部分に気抜きを兼ねた回転 空が1周を16分割し配される。そして、この 2 フィート程高い屋根ま で煙突が立ち上がり、煙突は直径2フィートの円筒に固定される。

つまり図面類から判断すると煙突は、円塔脚部1層目床に置かれる 予定であった煖爐上から立ち上がり6層目へ、続いて円塔脚部を貫き 水槽タンク中央にある中空の円柱内部を通り、屋根中央頂部の円筒 立ち上がり部分に達する構成となっていたことが判明する。なお、 屋根中央円筒立ち上がり部分における屋根の構造は明らかではない が、設計段階では当該部に排煙の機能を持たせたものと判断される。

\section{3-4 旧中島浄水場配水塔の実態}

それでは実際の旧中島浄水場配水塔において、これらの設備はど のように装置されているのだろうか。次にこの点を確認したい。

円塔脚部1目中央に現状で暖房及び煙突は設置されない。また2層 目から6層目でも煙突は配されず、2層目以上の各層床面中央に四角 形の穴が開けられるのみで、現在この部分は板で仮設的に塞がれる。

また、円塔脚部最上部となる6層目床上からは水槽タンク下部を観 察することができる。これによると水槽タンクの中央部分には中空 円柱のみが図面通り配され、煙突は設置されていない。

水槽タンク上部、即ち中空円柱上では屋根の小屋組であるワーレ ントラスの小屋組陸梁が集中する。但し、トラスは一材で直径方向 に連続することはなく、図面の項目で示したように、トラス陸梁の 中央側端部は環状の材にリベット止とし、トラス陸梁と中空円柱は 斜材の山形鋼で接続される。

屋根頂部では2部材からなる円筒が確認され、これらは小屋根小屋 組を受け、屋根中央の立ち上がり部となる。立ち上がり部の屋根は 下部から観察すると外光が確認される。外部から見ると、円塔外周 に取り付けた山形鋼が屋根を受け、屋根は円錐周囲に垂直の円柱部 分が取り付くため、この部分は図面とやや異なる納まりとなる。

なお、現状で中央に立ち上がる屋根頂部部分は部材がやや新しい ものと判断できるため、昭和 58(1983) 年の改修において、現状の形 式に改められたと見ることができよう。

つまり現状の配水塔では煖爐や煙突は確認されないものの、円塔 脚部 1 層目に煖爐を設備した場合、煙突は円塔脚部各層中央の穴を 通じて水槽下部へ行き着き、次いで鋼鉄製水槽の内部中央を貫き、 更には現在小屋組のトラス材を受ける円筒を通じて屋根上部に達す ることのできる施工の行われたことが判明する。

\section{4. 長岡市旧中島浄水場配水塔と水槽タンクの形状}

ところで旧中島浄水場配水塔における鋼鉄製の水槽タンクは、下 部が円錐台型にすぼまり、底面は凸型に反転する形状を有する。そ してこれを支える円塔脚部は、いわゆるお椀型となる水槽タンク部 下部を支える高台部分を受け、上部にややすぼまった円錐台形とな る。このため配水塔全体の容姿としては円塔脚部と水槽タンクの接 続部分が極端にすぼまる、いわゆるこけし型となる。

また、水槽タンク下部には引出管（取水管）、引入管及び余水吐管 が取り付く。引入管及び余水吐管は水槽タンク中心から 4 フィート と中心に近い位置に配されるが、引出管は８フィート6インチと中 心からやや離れた凸型反転部外周付近に配されることとなる。

次いで、配水塔及び水槽タンクの形状と管類の配置について戦前 期建設の公共上水道における配水塔と比較した性格を見て行きたい。

\section{4-1 戦前期の配水塔の形状}

戦前期に建設が確認される公共上水道における配水塔施設 65 基の 内、51基の形態が表 1 に示したように図面、写真などから明らかとな る。51基の内、台となる脚部に壁面を設けず軸組のみとする6角錐台 形、水槽タンク部分を円柱の形態とするものが最も多く 20 基、類似 する脚部を 8 角錐台とするものが4基、4角錐台とするものが 2 基、合 計すると 26 基で、これが全体の半数以上を占める。一方、脚部に壁 を設け全体を円柱、水槽タンク部を半径の異なる円柱状となるもの が6基、全体が円柱となるものが5基、円柱に水槽タンク部が半球状 となるものが 4 基でこれらの合計が 15 基となり、この他、円錐台型の 脚部に円柱型の水槽タンク部の載るものが4基となる。

ところで、長岡市旧中島浄水場配水塔で見られた円錐台型の脚部 にお椀型の水槽タンク部が載る、いわゆるこけし型の形態は戦前期、 において長岡市の配水塔にしか確認できない特徵的な形態である。 なお、類似するものでは6角錐台の脚部にお椀型の水槽タンク部を載 せる形式が戦後に上福岡市上水道とされた現ふじみ野市における旧 陸軍省造兵廠福岡工場の配水塔において確認されるのみである注 322

\section{4-2 戦前期の配水塔の水槽タンクの形状}

戦前期の公共上水道の配水塔65基の内、52基の構成が判明する。 35 基が鋼鉄製の水槽タンクを備え、内 4 基が水槽タンク外側を鉄筋コ ンクリートで覆う。また 35 基の内、8基は下部の形態が明らかではな いが、残る 27 基の内、 8 基が底部を水平、19基が半球型とする。底部 を水平とする 8 基の内、 5 基が脚部を $\mathrm{RC}$ 造として、水槽タンクの受け 部分を梁組で床面を設けるが、残り 3 基は新潟県旧巻町、旧亀田町、 旧水原町のもので、容積が順に $140 \mathrm{~m}^{3} 、 208 \mathrm{~m}^{3} 、 220 \mathrm{~m}^{3}$ と比較的小規模 の部類に入るものである。さて、鋼鉄製水槽タンクで下部を半球型 とする残りの19基の内 18 基までが下部における半球の形状は下に凸 とするが、唯一、今回考察の対象とする長岡市旧中島浄水場配水塔 が鋼鉄製水槽タンク下部の形状を上に凸とし、その特異性が際立つ。

\section{4-3 戦前期の配水塔の水槽タンクへ取水管の取り付き位置}

戦前期に公共上水道において建設された配水塔65基の内、水槽夕 ンクからの取水管取り付け位置が判明するものは40基である。この 内、取水管の取り付きが水槽タンク下部中央となるものが 32 基、周 辺が8基となる。但し、周辺に取水管が取り付く8基の内、7基までが 水槽タンク底部を水平にするもので、底部が凸型となるもので取水 管が周辺に取り付く事例は長岡市旧中島浄水場配水塔の水槽夕ンク に限られ、やはり独特な構成と見ることができる。 
表 1 戦前期の公共水道施設における配水塔と脚部、水槽タンクの形態

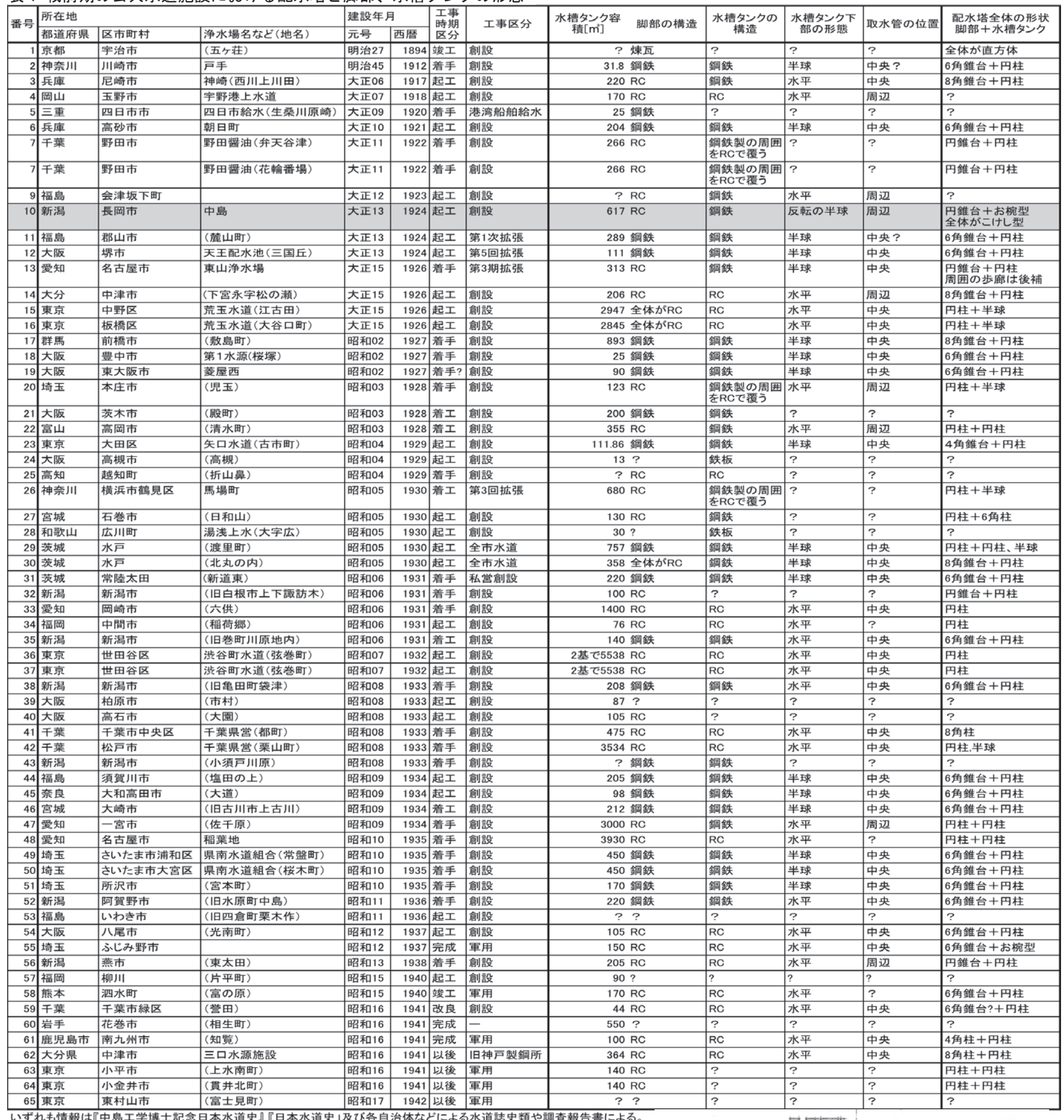

いずれも情報は『中島工学博士記念日本水道史』『日本水道史」及び各自治体などによる水道誌史類や調查報告書による。

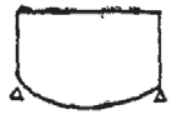

a<smiles>C1CC2CC1C2</smiles>

C

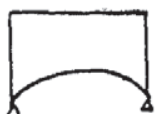

$b$

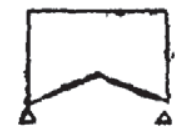

d

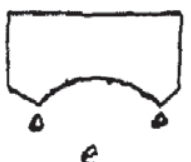

図 2 槽底の形 草間偉: 上下水道、190 頁、昭和 4(1929). 3, より

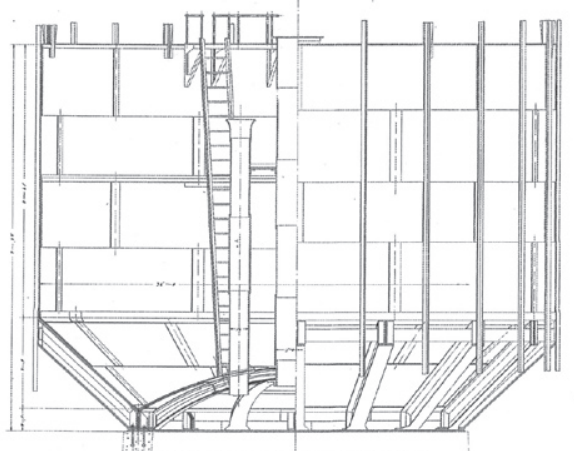

図 3 長岡市上水道配水塔設計図水槽一般図 長岡市水道局所蔵 


\section{5. 長岡市旧中島浄水場配水塔の設計}

\section{5-1 インツェ式タンクの効用と煙突}

水槽タンクの下部を反転させる形式は図2に示したように戦前期、 インツェ式の呼称で既に紹介されている。この形式では周壁と底板 との結合は特に丈夫にする必要があるものの、水槽タンクを支える 場合、半球型に比べ下部円塔脚部への積載が都合よく、ドイツにお いてしばしば用いられたとする注33)。しかし、上で見たように戦前 期における日本における採用事例は長岡市旧中島浄水場配水塔に限 られる。

なお、この形式が他と異なるのは

(1)水槽タンク下部が上に凸の形状

(2)取水管が水槽タンク周辺部に取り付く

の2点であることが明らかである。但し(2)については、取水管を水槽 最深部に取り付けるという原則に従えば、水槽タンク下部において、 取水管の取り付く場所が当該水槽における最深部直近となっている こととなる。つまり、この水槽タンクにおける特異性は “1 1)下部が 上に凸の形状”という点に依拠することとなる。それでは、この形 状はどのような理由に基づいて採用されたのであろうか。

既に記したように、長岡市旧中島浄水場配水塔では、冬季におけ る水槽内水結の防止のため、円塔最下層に煖爐及び円筒及水槽の内 部中央を貫いて煙突を設けることの計画を行い注 34$) 、$ 施工した。つ まり計画では煖爐からの排煙は、水槽タンク中央を貫く中空の円柱 内を通って屋根頂部に向から一方、最下層床上の煖爐により暖めら れた暖気は、2層目以上の各層床面中央に設けられた穴を通り、各層 室内も加温し、同時にここを貫通する引出管、引入管及び余水吐管 も保温しながら徐々に上層へ向かって円塔脚部6層目上に載せられ た水槽タンク下へ集まり、最終的には水槽タンク内部に揚水された 浄水の加温を行うのであろう。つまりこの時、水槽タンクが一般的 な下に凸型となる半球型の形状であると暖気は水槽タンク下に滞留 しづらいこととなる。しかし水槽タンク下部が上に凸となる反転し た球状であると、ここに暖気は留まりやすく、結果として水槽タン ク内の水結を防止することとなるのであろう。なお、この暖気は最 終的には、水槽タンク中央、煖爐からの煙突が配される中空の円筒 際をたどり、屋根の中央頂部から排気されるのは前述の通りである。

以上のように、長岡市旧中島浄水場配水塔水槽タンク下部が上に 凸の球状となるのは、冬期における水槽タンク内の水結を防止する ためで、円塔最下層に設置することができた煖爐により加熱された 暖気を水槽タンク下で効果的に留めるためと考えることができる。

\section{5-2＼cjkstart水槽タンク外側の防寒壁}

ところで旧中島浄水場配水塔水槽タンク周囲には水槽タンク周壁 から外へ4フィート6インチの巾で外壁が防寒のため設置された。設 計段階における構造は鉄材で架構し、外部はRC造、内部には木材を 張り、外壁との間には歩道を設けるとする。つまり、現在見る直径 45 フィートの水槽タンク部は外壁がなければ直径 36 フィートとなる。 旧中島浄水場配水塔では円塔脚部上部外径が24フィートで、水槽 タンク部直径45フィートより極端にすぼまる点に他と比較して形態 の特徴を見ることができた。逆にいえばこの配水塔ではRC造の円塔 脚部上に、お椀型となる水槽タンク部を円塔脚部から迫り出寸が、 水槽タンク部では更に防寒用の外壁が水槽タンク両側へ4フィート 6
インチずつ拡幅されることで、円塔脚部上部両端から水槽タンク部 がより大きく迫り出す効果を強めていると言える。

\section{5-3 円塔脚部の外壁}

配水塔脚部の設計にS造を用いる場合、脚間に壁を設けること極め て稀である(注35)が、塔脚部をRC造とし、配水塔が堅管式を採用して 大容量となる場合は当然、壁を有するが、高架式配水塔の場合、脚 部における壁の有無は設計者の判断に委祆られることになる注36)。

戦前期の公共上水道における配水塔施設 65 基の内、脚部回りの構 造が明らかとなるものは51基で、脚部に壁を有しないものが高架式 の 27 基、この内、 $\mathrm{S}$ 造は19基、 $\mathrm{RC}$ 造は8基となる。一方、脚部に壁を 有するのは残りの 24 基で、煉瓦造 1 基、 $\mathrm{S}$ 造 1 基、 $\mathrm{RC}$ 造が 22 基で、内訳 は堅管式がいずれもRC造の8基、残り16基が高架式となる。

以上の結果から見ると、高架式で塔脚部をRC造とする 23 基でも 7 基が壁を有さず、壁の有無は設計に当たり、様々な要因により判断 が別れると見ることができる。

長岡市旧中島浄水場配水塔は高架式で脚部をRC造とするもので、 脚部は壁を有する形式となる。この形式を採用した理由は上述した 『長岡市上下水道小誌』などにも記されないが、これまで述べて来 たように、本配水塔では水槽内の水結防止のため脚部全体を加温す る考えから脚部における壁面は不可欠のものであった言える。

即ち、長岡市旧中島浄水場配水塔が高架式の形式で脚部に壁面を 配した点も、寒冷地仕様の考えに基づくと判断できるのである。

\section{6. 長岡市旧中島浄水場配水塔にみる造形的な特徵}

以上見てきたように旧中島浄水場配水塔は、円塔脚部の台座上に 迫り出した水槽タンク部分が載るいわゆるこけし型となり、これは 戦前期における公共上水道における配水塔と比較した場合極めて特 徵的な形態であることが明らかとなった。

この形状をなった根本的な理由は、水槽タンク部に、いわゆるお 椀型となるインツェ式を採用したことが大きく寄与する。ところで、 インツェ式の採用は水槽タンク下部が反転して上に凸の形状となる ことから冬期における凍結防止のため、暖気の滞留を目的としたこ とは明らかであった。加えて、水槽タンク周囲には冬期における防 寒を目的に歩道を伴う外壁が設けられたことは、円塔脚部から迫り 出す水槽タンクの形状を一層強調させた。また、円塔脚部外周おけ る壁面の採用も、上述した加温に対し不可欠の装備と言える。

即ち、長岡市旧中島浄水場における特徵的な形態の要因であるイ ンツェ式タンク及び水槽タンク外壁、円塔脚部壁面の採用はいずれ も、寒冷地に対する仕様に基づくものと言える。その結果、配水塔 の立面形態は、この時期、国内では他には見ることのできない、い わゆるこけし型となり特色ある形態を示すものとなった。

つまり、長岡市旧中島浄水場配水塔は、長岡における冬期における 環境的条件を考慮し、地域に適した技術と形態の在り方を探求した 結果の造形設計とすることができるのである。

なお、このように特色ある形式のインツェ式タンクではあったも のの、国内において一層の普及を見なかったのは、この後、配水塔 水槽では、防寒で優る RC造注 37 が多くを占めたためと考えることが できよう。

7. さいごに 
長岡市旧中島浄水場配水塔の形態について、造形設計の観点から 考察を加えたが、明らかとなるのは以下の諸点である。

1) 配水塔円塔脚部2層目以上の各層中央に残された穴は、設計時 においては、水槽タンク凍結防止用の暖房の煙突を設けることが できる設備としたものの、煙突は設けられなかった。

2 ) 設計において配水塔内に設けられた煖爐の煙突は円塔脚部2層 目以上の各層中央を貫き、水槽タンク中央に設けられた中空の円 柱内を抜け、屋根頂部にまで達するものであった。

3 ) 水槽タンクの形状に下部が上に凸の球状となるインツェ式が採 用されたのは、円塔脚部最下層に設置可能であった煖爐によって 加温された暖気を水槽タンク下部へ効率的に留め、水槽タンク内 の水結を防ぐとの考え方に基づくものと言える。

$4 ）$ 水槽タンク外周に通路と外壁を設けたことで、円塔脚部から迫 り出す水槽タンクの形状が一層強調されている。

5 ) 円塔脚部外周に装置された壁面は、加温時には不可欠の装備で ある。

6 ）インツェ式タンク、水槽タンク外周外壁、円塔脚部外周壁面の 採用は、いずれも寒冷地という長岡の環境的条件に対応したもの で、その結果、配水塔の立面は、特色あるこけし型を示すものと なった。

7 ）長岡市旧中島浄水場配水塔は、長岡の冬期における環境的条件 を考慮し、地域に適した技術と形態の在り方を探求した結果の、 特色ある造形と見ることができる。

\section{参考文献}

1）中島工学博士記念事業会：日本水道史、 1927.8

2）社団法人日本水道協会 : 日本水道史各論編II中部近畿、1967.3

3）長岡市役所：長岡市上下水道小誌、pp. 2 4、1927. 3

4）草間偉：万有科学大系続編 12 上下水道、1929.3

5）河口協介・茂庭忠次郎 : 高等土木工学12 上水工学下水工学、1931.11（上 水工学分は河口協介の著作)

6) 岩崎富久 : 衛生工学上水道、1935.11

7）伊東孝：明治期における東京鉄製道路橋と技術者群像一倉田吉と金井彦三 郎に焦点をあてて一、土木史研究25、pp. 27〜37、2006

\section{注}

注 1) 参考文献 2) 10 頁。“工事は昭和 2 年 (1927 年) 3 月末、工事費 $1,548,782$ 円 93 銭をもつて完成した。とある。

注 2）国の登録名称は“水道タンク”とするが、後述する水道誌類では “配 水塔”の名称のため、本稿でも“配水塔” の呼称を用いる。

注 3）参考文献 3）、2 4 頁、では、後掲のように円塔の “内部には鉄筋混凝 土造床四層を以て間仕切をなし”とするが、図面類を確認すると 5 層目上、 則ち 6 層目となる胸壁(パラペット)上に水槽タンク部が載ることとなる。

注 4）参考文献 3）、2〜4 頁、などでは “円塔部”とするが、水槽タンク部と の相違を明らかとするため、本稿では“円塔脚部”の呼称を用いる。

注 5）参考文献 3)、24〜25 頁

注6）参考文献6)、212頁、では “寒地では槽中の水の水結を防ぐ為、其の外 側を更に防護壁で保温する”とある。また、参考文献5)、236頁、では“鉄 板槽の場合は槽中の水に外気温度の影響を与へない様にする為に其の外 側に0.3〜 $1.0 \mathrm{~m}$ 空隙を作つて二重槽とし場合によつては鋸屑コルク等の 如き熱の不良導体を充填して置くがよろしい”として断熱のため防寒壁を 設けることが当時、一般的であったことが分かる。

注 7）高岡市役所：高岡市水道誌、73 頁、昭和 9(1934).7

注 8）来歴と施設全般は、参考文献 3 )、2 4 頁、を参考とした。

注 9) 平山：大正 9(1920) 年の長岡市上水道計画の概要：「水道タンク」は なかった大正 $9(1920)$ 年の上水道計画、長岡造形大学紀要 3、71〜86 頁、 平成 18(2006). 3

注 10）長岡市:長岡市政 100 年の歩夕、25 頁、平成 18(2006).3

注 11）参考文献 1）、429～432 頁、参考文献 2）、9～14 頁
注 12）参考文献 3）、23～25 頁

注 13）長岡市上水道配水塔設計図水槽一般図、長岡市水道局蔵

注 14）長岡市上水道配水塔設計図水槽斜板之図、長岡市水道局蔵

注 15）長岡市上水道配水塔設計図水槽底板之図、長岡市水道局蔵

注 16）参考文献 3）、23～25 頁

注 17）配水塔第八号、長岡市水道局蔵

注 18）参考文献 3）、23～25 頁

注 19）参考文献 3$) 、 2 \sim 3$ 頁

注 20）平山：前橋市敷島浄水場の当初配水塔について、日本建築学会関東支

部報告集 II 78、357 360 頁、平成 20 (2008).2

注 21）参考文献 6)、212 頁、

注 22）参考文献 1)、843～855 頁

注23）中島鋭治の著作としては(1)小都会ノ水道事業ヨ私立会社二許可スルノ 途ヨ開クベキノ議、明治27 (1894). 12、(2)東京市水道要覧抜萃、明治 29 (1896).4、が挙げられる。また、序を記したものでは(1)瀬賀熊太郎編： 土木工学 治水編、明治29(1896). 10、(2)亀井重麿 : 市町村の水道、大正 15(1926).1、がある。

注24）金井の来歷は(1)一記者：私学のダイヤモンドたりし金井彦三郎氏、土 木建築工事画報8-2、49頁、工事画報社、昭和7 (1932). 2、(2)藤井肇男：土 木人物事典、97頁、アテネ書房、平成14(2004). 12、(3)参考文献7)、など によった。

注 25）参考文献 7)、34 頁

注 26) 平山：長岡市旧中島浄水場配水塔の完成年は大正 15 (1926) 年か昭和

2 (1927) 年か、日本建築学会北陸支部研究報告集 56、平成 25 (2013). 5

注 27）北越新報社：北越新報、大正 15 (1926).7/13、2 頁

注 28）北越新報社：北越新報、大正 15 (1926).7/13、2 頁

注 29）参考文献 3)、23～25 頁

注 30）飯島一郎：長岡市水土雪害状况及び其の対策に就いて、水道協会雑誌

35、52 頁、昭和 11(1936). 4

注 31）長岡市史編集委員会近代史部会編：長岡市史双書 12 統計にみる長岡 の近代、平成 2(1990). 3

注 32）上福岡市立歴史民俗資料館：資料館調查報告 1 旧陸軍の施設 特に造 兵廠福岡工場 (川越製造所)を中心に、28 頁、平成 4(1992). 3

注 33）参考文献 4)、190 191 頁

注 34）参考文献 3)、23〜25 頁

注 35）戦前期の日本では水戸市低区配水塔がその唯一の事例となる。

注36）参考文献4）、188～191頁。同書で竪管式には“じゅかんしき”（厳密に は旧かな使いで “じゆくわんしき”)の振り仮名を付し、スンドパイプの 英名を加える。

注 37）参考文献 4）、191 頁では “鉄筋コンクリート槽 鉄筋コンクリートは 又屡々竪管又は高架水槽に応用せられる。設計施工宜しきを得ると鋼槽よ りも希望通りの形に出来外観も善く冬凍る心配も少なき点にて優つて居 る”とする。 


\section{STUDY ON THE DESIGN IN THE FORM OF \\ THE FORMER NAKAJIMA WATER PURIFICATION PLANT WATER TOWER \\ IN NAGAOKA CITY}

\section{Ikuo HIRAYAMA*}

* Prof., Faculty of Design, Nagaoka Institute of Design, Dr. Eng., Dr. Des.

I considered the form of the former Nakajima water purification plant water tower in Nagaoka city from the viewpoint of design, and the following points become clear.

The hole left for the center of each cylindrical tower bent floor of the water tower were designed as the facilities which could establish the chimney of the anti-tank freeze heating, but the chimney flue was not made.

The chimney of a fireplace put in a water tower at a design stage went through a cylindrical tower bent and, through the column of the water tank center, reached top of the roof.

The reason why a Jince type was adopted to a water tank was to keep genial climate warmed with the stove on the cylindrical tower at bent bottom layer to the retainer of the tank, and to prevent the freezing in the tank.

The adoptions of the Jince type tank, the outer wall of the tank and the cylindrical tower bent circumference wall surface meet all the environmental condition in cold districts.

As a result, it became that the vertical plane of the water tower showed a certain characteristic kokeshi doll tyle.

The water tower at the former Nakajima water purification plant was designed with the results searched the technique suitable for Nagaoka area and the way of the form in consideration of an environmental condition in the winter season.

The adoptions of the Jince type tank, the outer wall of the tank and the cylindrical tower bent circumference wall surface meet all the environmental condition in cold districts.

As a result, it became that the vertical plane of the water tower showed a certain characteristic kokeshi doll tyle.

The water tower at the former Nakajima water purification plant was designed with the results searched the technique suitable for Nagaoka area and the way of the form in consideration of an environmental condition in the winter season. 